\title{
Vol. 70, No. 29
}

In the report, "Heat-Related Emergency Department Visits During the Northwestern Heat Wave - United States, June 2021," on page 1020, the last sentence of the first paragraph should have read, "The record-breaking heat had the largest impact in Oregon and Washington, especially the Portland metropolitan area, with temperatures reaching $116^{\circ} \mathrm{F}\left(46.7^{\circ} \mathrm{C}\right)$, which is $42^{\circ} \mathrm{F}\left(23.3^{\circ} \mathrm{C}\right)$ hotter than the average daily maximum June temperature." 